AperTO - Archivio Istituzionale Open Access dell'Università di Torino

\title{
Fashion as an Institutional system
}

\section{This is a pre print version of the following article:}

Original Citation:

\section{Availability:}

This version is available http://hdl.handle.net/2318/1693878

since 2019-02-21T12:48:45Z

Terms of use:

Open Access

Anyone can freely access the full text of works made available as "Open Access". Works made available under a Creative Commons license can be used according to the terms and conditions of said license. Use of all other works requires consent of the right holder (author or publisher) if not exempted from copyright protection by the applicable law. 
Paolo Heritier*

\section{Fashion as an Institutional System}

DOI 10.1515/pol-2016-0002

Abstract: The analysis of the relationship between fashion and institutions could represent a new approach in the theoretical analysis of fashion. This article is an attempt to show how, from an analysis of Simmel, Lotman, Volli and Legendre and a semiotic-juridical perspective, the topic of fashion can be linked to an anthropological-juridical perspective and a juridical conception of fashion as a normative 10 institution. Juridical knowledge appears to be essential for the anthropological understanding of the phenomenon of fashion and too many studies have forgotten the contribution of the juridical sciences to the theoretical configuration of the question. From a complex historical-juridical analysis of the notion of Corpus Iuris (Kantorowicz) emerges the value of the medieval notion of corpus mysticum as a fictional body, referring to a political context that is both liturgical and ritual. The reference to this idea thus passes from the Corpus Iuris Civilis of medieval canonical law to the modern aesthetic signification (fictional and iconic) of the notion of the political body, referring to the modern state, which is still to be found on the well-known frontispiece of Hobbes' book the Leviathan and then to the 20 fictional and stylised bodies of the models in a fashion show. Following the theories of Legendre, the conclusion of this article suggests to reintroduce the secularised juridical and theological lexis for the aesthetic relationship between the natural body and the fictitious body, seen as a mystical and political body, considered present in the practices of dressing and twentieth-century fashion. Fashion is one of 25 the forms through which, in mobilising desire, the human being constructs that "second body", fictitious, represented, parallel to the real body, which is constitutive of the subjective and collective identity of a society. This body is fashioned under the ritualised and institutionalised form of the garment that hides the body, concealing its animality, which gives access to a collective fictitious reality, of 30 which, we could add, all the products of the semiosphere, including the juridical institutions, are formed.

Keywords: fictional body, institution, Corpus Iuris, model, semiosphere

The word and the garment are two specific prerogatives of Man that distinguish him from other animals. It is known that some animal species enact behaviour 
similar to the adoption of means of communication and disguise, elaborating 1 non-verbal languages and strategies in order to alter their appearance in given situations (predatory or reproductive, for example), without, however, creating genuine objects independent from the body itself (clothes, books and other noncorporeal "written" surfaces). Man, on the other hand, during his evolution, has 5 progressively identified a specific, mental space, and objects linked to this space that we could call space for representation, a sphere concerning the human semiotic phenomena, inasmuch as they are distinct from the sphere of natural phenomena. This division between the sphere of the physical and the realm of the cultural can of course be expressed in many ways and even anthropologi- 10 cally criticised in depth ${ }^{1}$; however, what we intend to do here is to show that the matrix denotes the sphere of the institutions as space other than the natural and the biological: we will conduct an analysis of the relationships between fashion and law that seems to be little-known and tends to consider, after a complex itinerary, fashion a normative institution.

A first step in this itinerary in search of the not immediately evident connections between fashion and the juridical institutions is a semiotic starting point, which can be referred to Lotman's theory. The distinction between the biological body and the garment, or between the biological body and language can in theory be traced to a well-known distinction presented by Lotman, which divides phenomena between 20 biosphere and semiosphere. ${ }^{2}$ It could of course also refer to many other theoretical approaches, of which some are particularly relevant in understanding the connection between the phenomena of fashion and the juridical sphere. We could, for example, compare the semiosphere, meaning "that same semiotic space, outside of which semiosis itself cannot exist," 3 to Popper's theory of the plurality of worlds and in particular to the theory of "World 3" as the world of human theories and creations, a sort of world of ideas seen from an evolutionistic and fallibilistic point of view. ${ }^{4}$ We will not, however, radically leave the problematic sphere to which

1 Philippe Descola, Par-delà Nature et Culture (Paris: Gallimard, 2005), for example, returns to this question from a critical standpoint.

2 Juri Lotman, “On the Semiosphere," Sign System Studies 33.1 (2005): 205-229.

3 Lotman, "On the Semiosphere," 208.

4 On the theory of the Worlds, Karl Popper, Objective Knowledge. An Evolutionary Approach 35 (Oxford: Clarendon, 1972), 45; Karl Popper, Knowledge and the Body-Mind Problem. In Defence of Interaction (London: Routledge, 1994), 106-108; Karl Popper, Unended Quest. An Intellectual Autobiography (London: Routledge, 1994), 210-225. On the theory of world 0 as an analogous place to the Popperian World 3, see Paolo Heritier, "From Text to Image. The Sacred Foundation of Western Institutional Order: Juridical-Semiotic Perspectives," International Journal for the Semiotics of Law 26.1 (2013): 163-190. 
Vernadsky's concepts of biosphere and noosphere refer - from which Lotman's 1 theory of semiosphere derives ${ }^{5}$ - as a network of complex interrelations that link the ambit of human life to the world of nature.

This is a research perspective, from which ecology and the theory of systems $^{6}$ and many other theories derive, that tries to link the various, closely 5 linked although conceptually distinct ambits. From this context, the analysis of the relationship between fashion and the institutions could represent a new approach in the theoretical analysis of fashion. In fact, authors writing from a sociological, ${ }^{7}$ communication theory or a semiological, ${ }^{8}$ philosophical and anthropological, ${ }^{9}$ psychological, ${ }^{10}$ economic, ${ }^{11}$ or historical ${ }^{12}$ point of view 10 have often dealt with the topic of clothing and fashion, but generally not from a juridical, in particular, a theoretical juridical point of view. ${ }^{13}$ This article is an

5 Lotman explains the difference between the biosphere and the noosphere in Vernadskij and his notion of the semiosphere, "On the Semiosphere," 206-208.

6 Silvano Tagliagambe, Epistemologia del Cyberspazio (Cagliari: Demos, 1997), 12 [my translation]. 7 Georg Simmel, "Fashion,” The American Journal of Sociology 62.6 (1957 [1911]): 541-558; Fred Davis, Fashion, Culture and Identity (London-Chicago: The University of Chicago Press, 1992); Yuniya Kawamura, Fashionology. An Introduction to Fashion Studies (Oxford/New York: Berg, 2005); Tim Edwards, Fashion in Focus. Concepts, Practices and Politics (Abingdon-New York: Routledge, 2011). 8 See Roland Barthes, Système de la Mode (Paris: Seuil, 1967); Ugo Volli, Contro la Moda (Milano: Feltrinelli 1988); Ugo Volli, Block Modes. Il linguaggio del Corpo e della Moda (Milano: Lupetti, 1998).

9 See Immanuel Kant, Anthropology from a Pragmatic Point of View [1798], (Carbondale, IL: Southern Illinois University Press, 1996); Herbert Spencer, Manners and Fashion in Essays: Scientific, Political and Speculative (London-Edinburgh: Williams and Northgate, 1891), 1-51; see also Michael Carter, 25 Fashion Classics. From Carlyle to Barthes (Oxford-New York: Berg, 2003): 19-40; Gilles Lipovetsky, L'Empire de l'Éphèmère. La Mode et son Destin dans les Sociétes Modernes (Paris: Gallimard, 1987). 10 See John Carl Flügel, The Psychology of Clothes (London: Hogarth, 1930); Joanne Filkelstein, The Fashioned Self (Cambridge: Polity, 1991).

11 See Thorstein Veblen, The Theory of the Leisure Class. An Economic Study of Institutions (New York: Modern Library, 1934 [1899]), see also Carter, Fashion Classics, 41-59; Ben Fine and Ellen 30 Leopold, The World of Consumption. The Material and Cultural Revisited (London: Routledge, 1993). 12 See Daniel Roche, La culture des Apparences (Paris: Fayard, 1991); Diana Colombo, Alle Origini della Moda. Dal Costume Nazionale al Sistema della Moda (Reggio Emilia: Diabasis, 2010).

13 If we exclude the field of so-called Fashion Law, a sort of positive analysis of the normative content concerning fashion (copyright, etc.) in the philosophy and social of law, fashion is mentioned as an institution by Niklas Luhmann and Enrico di Robilant. Initially Ingrid Losheck, 35 after having noted how "Fashion as a system is equated with the systems Luhmann laid down such as politics, economics, sport, religion and art" points out that "Luhmann itself did little to investigate fashion. He mentions fashion [...]” Ingrid Losheck, When Clothes become Fashion. Design and Innovation Systems (Oxford-New York: Berg, 2009). See also the debate with Schwarz: Niklas Luhmann, "Udo H. A. Schwarz. Das Modische," Soziologische Revue 7 (1984): 73-74 e Udo H. A. Schwarz, "Replik auf die Rezension von Niklas Luhmann," Soziologische 40 
attempt to show how, moving from a semiotic-juridical perspective, the topic of 1 fashion can be linked to an anthropological-juridical perspective and a juridical conception of fashion as a normative institution.

The theory that we wish to put forward is that juridical knowledge is essential for the anthropological understanding of the phenomenon of fashion 5 and that too many studies have forgotten the contribution of the juridical sciences to the theoretical configuration of the question. Given its complexity and breadth, the question of the connection between fashion and custom will not be analysed, since it would require an analysis of the topic of contemporary theory of the sources of law. ${ }^{14}$

\section{A semiotic view of fashion}

According to Lotman's analysis, starting from a semiotic point of view always implies, even in such diverse perspectives as those of Peirce - founded on the notion of signs - and that of Saussure - connected to the distinction between language and speech - a common trait: structuring semiotics beginning from a simple and atomic starting trait, whether it is a succession of signs or a com- 20 municative act, according to a perspective that moves from the reduction of the complex object to its simple atomic components. Lotman's theoretical interest is, on the other hand, to be considered the semiotic process as referred to a totality that cannot immediately be broken down, and for this reason he refers to Vernadsky's notions of biosphere and noosphere. In fact, while for this author 25 the biosphere can be conceived as a cosmic mechanism, situated on the surface

Revue 7 (1984): 74-76. Also Robilant simply mentions fashion alongside the five informativenormative systems that he considers most relevant, that is to say science, technology, law, 30 economics and guidance. His methodological configuration is however able to note the aesthetic legality of the fashion system, comprised in a perception of the norm as an informative message in the complex society. On these aspects Enrico di Robilant, "Sistemi informativonormativi e operatività nella società complessa,” in Studi in Memoria di Giovani Tarello, Vol. II. Saggi Teorico-Giuridici (Milano: Giuffrè, 1990), 405-431 and, more extensively Enrico di Robilant, Diritto e Selezione Critica (Giappichelli: Torino, 1997). On the informative-normative 35 systems in Robilant, extensively, Paolo Heritier, "La Rete tra il Testo e il Diritto. Verso un' Ermeneutica Figurale?," in Prolegomeni di Informatica Giuridica, ed. Ugo Pagallo (Padova: Cedam, 2003), 205-227 and Heritier, "From Text to Image," 165-170.

14 On this vast topic we would mention the contributions of Filippo Gallo, Consuetudine e Nuovi Contratti. Contributo al Recupero dell'Artificialità del Diritto (Torino: Giappichelli, 2012) and Patrick Nerhot, La Costume. Le Droit Muet (Torino: Giappichelli, 2012). 
of our planet and including the totality of living things, that "transforms the 1 radiated energy of the sun into the chemical and physical, and is concerned with the transformation of the inert inanimate materials of our planets," the noosphere is a distinct phenomenon, but linked to the biosphere, which "occurs when human rational activity acquires a dominant role in this process."

For Lotman the semiosphere can be understood as the totality of individual texts and isolated languages "as they relate to each other." As we have said, with regard to the biosphere he emphasises its primacy with respect to the individual organisms, while in a traditional vision of semiotics all the linguistic structures "will look as if they are constructed out of individual bricks." For the notion of semio- 10 sphere, however, according to Lotman, it is in fact preferable to think in a different manner, as if "all semiotic space may be regarded as a unified mechanism (if not organism)."16 In this manner, it is possible to understand the primacy of the semiosphere over the sign or the linguistic act: it is "that same semiotic space, outside of which semiosis itself cannot exist,"17 equipped with specific characteristics, such as 15 the existence of confines and irregularities, or it can be defined as "the semiotic space necessary for the existence and functioning of languages, not the sum total of different languages." 18

This synthetic presentation of the semiosphere and its heterogeneousness explains how we are immersed in language as something that precedes us but 20 within which we move, ${ }^{19}$ and from which its original ambiguity derives: "we need to exert a tremendous effort to push ourselves beyond the limits of language and it is precisely to language that we ascribe our lies, deviations from the norm, and the majority of our defects and perversion." ${ }^{20}$ The spatial heterogeneousness of the semiosphere introduces the problem of temporality 25 and dynamicity, essential factors, as we will see, in understanding both law and fashion in their enunciations and differences, as part of the semiosphere. It is interesting to note how Lotman refers to both the juridical technique of inclusion of the Roman empire and Roman law and to fashion in order to explain this concept. In On the Semiosphere the distinction between centre and periphery, 30

15 Lotman, "On the Semiosphere," 207.

16 Lotman, "On the Semiosphere," 208.

17 Lotman, "On the Semiosphere," 208.

18 Juri Lotman, Universe of the Mind. A Semiotic Theory of Culture, trans. Ann Shukman (Bloomington, IN: Indiana University Press, 1990), 123.

19 "We cannot extract ourselves from space, which simply envelops us, and yet it is a space of which we are also a part and which, simultaneously, is a part of us.” Juri Lotman, Culture and Explosion, trans. Wilma Clark (Berlin, New York: Mouton de Gruyter, 2009), 114.

20 Lotman, Culture and Explosion, 114. 
characteristic of the notion of semiosphere, is represented by the example of the 1 expansion of the influence of Rome through the inclusive technique of its influence (and therefore its law): "a cultural area, growing rapidly, incorporates into its orbit external collective (structures) and transforms them into its own periphery."21

However, the economic and cultural development of peripheries induced by the attraction towards the centre steadily, as Lotman observed, alters the structure of the centre in turn, activating the transformation of the cultural structures. In this process the distinction between centre/periphery is effectively replaced by the distinction yesterday/today, thus highlighting the emergence of new 10 semiotic structures that become hidden/visible. This is a generalised process, which indicates the way in which the temporality of changes in the semiotic system is extremely variable, which does not preclude the perception of the constancy of the structure (of the dynamics of the change). Lotman compares, precisely on this question, fashion and language, "if in our time female fashion 15 in Europe has a durational speed of change of a year, then the phonological structure of language changes so slowly that we are inclined to consider it, on the basis of our common sense, constant."22 Law and fashion stand in the semiosphere as dynamics of change supported by different but similar logics. We can thus understand that which for Lotman represents the specific dynamic 20 of change of fashion (but also, in part, of the juridical phenomena and in general of the "inverted world") defined as the dynamic that is based on a "non-dynamic." The world of fashion, in fact, "introduces a dynamic principle to those spheres of life which appear to be non-dynamic" and not all civilisations, therefore, hold within themselves a phenomenon like fashion: "In societies, 25 where types of clothing are strictly subordinated to tradition or are dictated by calendrical changes - and anyway do not depend on linear dynamics and the arbitrariness of the human will, there may be expensive and cheap clothing but there is no fashion." ${ }^{23}$ It is not by chance, therefore, that fashion is characterised by attributes that are variable, capricious, strange, as it were, without reason 30 and marked by arbitrariness, while at the same time manifesting a specific trait of normativity (as we will see also juridical, not to mention linguistic normativity): the imposition through a dynamic that enunciates the (pretence of) constancy and a sudden and partially unforeseeable change.

21 Lotman, “On the Semiosphere," 212.

22 Lotman, Culture and Explosion, 114.

23 Lotman, Culture and Explosion, 79. 
In the cultural space of clothing there is a constant battle between the tendency toward 1 stability and immobility (this tendency survives psychologically, justified by tradition, habit, morals, historical and religious considerations) and an opposing orientation towards novelty and eccentricity - in short everything that ties into the idea of fashion. Thus, fashion appears to be the visible embodiment of unmotivated innovation. This allows it to be simultaneously interpreted as both the site of deviant whim and as the sphere of 5 innovative creation. Eccentricity is a prerequisite of fashion. The latter is not negated by the periodic resurgence of a traditionally oriented fashion since tradition itself is, in this case, an extravagant form of the negation of eccentricity. To include a specific element in the space of fashion means making it noticeable, allotting significance to it. Fashion is always semiotic. Included in fashion is a continuous process of the transformation of the insignificant into the significant. ${ }^{24}$

We can therefore draw a first conclusion. Fashion, according to Lotman's analysis (we observe: exactly like the linguistic and juridical phenomenon) participates in a semiotic structure of change that relates differently to the (pretence of) stability. If the linguistic phenomenon - to which we could add the juridical phenomenon as quite similar in this aspect - in effect needs a presupposition of continuity (which conceals the reality of a somewhat slow change) on the contrary, fashion belongs to the same inverted dynamic but is based on different presuppositions: the idea of its arbitrariness and of the presupposition of its constant and abrupt changing. These differences, in fact hide a similar semiotic reality in the structure of the dynamics of change in fashion, in language, and in law, within the heterogeneous course of the borderline dynamics of the phenomena of sense of the semiosphere.

Again with reference to fashion, another semiotic contribution appears quite useful in identifying proximity between the fashion system and the evolution of the juridical system, an investigation that is propaedeutic in analysing, in the next 25 section, a genuinely juridical vision of the institutionality of fashion. Ugo Volli, in reasoning on the millennial changes in relation to the phenomenon of fashion - its relations with the postmodern - observes that the twentieth century was the century of fashion:

The century that is about to end has truly been the century of fashion, its great triumph. Probably not the century of elegance, which was probably the sixteenth century, nor that of luxury and whims (the eighteenth century) but that of fashion, of the great oscillations of taste guided and dominated by the personality of the great tailors, couturiers and stylists. The willowy, floral women of Poiret, the garçonnes of the twenties, the deceptively simple images of Coco Chanel, Dior's human tulips, the feminists with their long flowered skirts and clogs, Armani's women managers... there has never been another historical period with the richness of invention and the fantastic capacity for collective metamorphosis. Fashion is not a destiny.

24 Lotman, Culture and Explosion, 79-80. 
In many great cultures there is no fashion: take for example India, ancient Egypt, ancient 1 Greece or Rome. Perhaps it is not by chance that there is an etymological link between fashion and modernity: it is when the new era emerges that in the Italian Comuni of the fourth and fifth centuries the collective and rhythmic change in taste emerges overwhelmingly. These changes are only the slow start; they take an entire generation, if not a century to become established. It is only with full modernity, with the invention of the haute couture shows and the figure of the 5 tailor-artist, perfected by Charles Worth almost one-hundred and thirty years ago, that fashion took on its nervous, contemporary intensity. ${ }^{25}$

This brief analysis, the fruit of a decade's work of the Milanese semiotician, which takes into account the many debates over an entire century, on the nature of 10 fashion, should of course be discussed and analysed. It shows that fashion is not a universal trait, but a phenomenon with a start and an ending. This idea begins to emerge also in relation to that particular dynamic of change that is Western law (not all societies and cultures have known - or know - law nor have they seen its role in the same way). Here, however, we are interested in noting how Volli's position takes up Lotman's historical reference to the Roman Empire, identifying in another historical period distant from modernity, the Middle Ages, the slow and progressive origin of the phenomenon of fashion seen as a modern phenomenon.

A similar historical theory has been extensively developed in the last twenty years by historians, in relation to the origins of the modern state: conceived as a 20 juridical-political phenomenon that, although clearly characterised by modernity, is rooted in the late Middle Ages and precisely the pontifical revolution of the eleventh century and the progressive formation of the Corpus Iuris Canonici as the double of the textual edifice of the Corpus Iuris Civilis. ${ }^{26}$ Although only sketched out, the inquiry into the phenomenon of fashion and the historical 25 examples cited by Lotman and Volli seem to characterise fashion just as the state in the important historical analyses cited by Berman, Legendre and Prodi

25 Volli, Black Modes, 8-9 [my translation].

26 See variously and from various perspectives, Harold Berman, Law and Revolution. The Formation of the Western Juridical Tradition (Cambridge: Harvard University Press, 1983); Ernst Kantorowicz, The King's Two Bodies. A Study in Mediaeval Political Theology [1957] (Princeton, NJ: Princeton University Press, 1981); Philip Nemo, Histoire des idées politiques dans l'Antiquité et au Moyen Age (Paris: PUF, 1998); Paolo Prodi, Il sovrano pontefice. Un 35 corpo e due anime: la monarchia papale nella prima età moderna [1982] (Bologna: Il Mulino, 2006). Pierre Legendre, La pénétration du droit romain dans le droit canonique classique de Gratien a Innocent IV (1140-1254) (Paris: Jouve, 1961), and Paolo Grossi, L'Ordine Giuridico Medioevale (Roma: Laterza, 2004). Recently, Legendre comes back to the subject: Pierre Legendre, Leçons IX. L'Autre Bible de l'Occident: Étude sur L'Architecture Dogmatiques des Sociétés (Paris: Fayard, 2009). 
indicates how the phenomenon is principally modern, but draws its origins from 1 a slow progress, a slow process that culminates in modernity, anticipated by the medieval and even Roman pre-modernity.

This theoretical analogy between law and fashion is even more evident if we continue the analysis of the discourse conducted by Volli at the turn of the 5 millennium, in relation to the presumed "modernity" of fashion and its transformations. If fashion becomes a synonym of modernity, it is interesting to ask oneself what comes after modernity, that is to say, the "strange configuration of cultural and social events generally called postmodernism" that the Italian semiotician describes as "the fall of ideologies, the impossibility of 'great stor- 10 ies', the loss of the sense of history, the pluralism and rather the confusion of the discourses and the images, the tendency to reproduce details from others' work, the miscegenation, the bizarre mixing of localisms and globalisation that dominates not only the economy and politics, but also the material culture, food and bodily expression," 27 a configuration of events of which fashion is consid- 15 ered "one of the victims."

Following the theory of a proximity between law and fashion, another of the victims of the phenomena following the postmodern that we would add to Volli's discourse, is certainly the positivistic conception of law and the idea itself of the exclusive sovereignty of the state, as we are about to see in the next 20 paragraph.

It is, however a question of better understanding what the normative traits of fashion are. Classic theories of fashion identify in the imitation of the richer classes an important element of the phenomenon of fashion. This is what Simmel, who sees imitation as a transfer of group life into individual life 25 which gives the individual the certainty of not being the only one to act, has to say. The individual is introduced into the universal according to logics that simulate the mass phenomena giving:

to the individuals the satisfaction of not standing alone in his actions. Whenever we 30 imitate, we transfer not only the demand for creative activity, but also the responsibility for the action from ourselves to another. Thus the individual is freed from the worry of choosing and appears simply a creature of the group, as a vessel of the social content. ${ }^{28}$

There is however also the opposite tendency in man, the search for the change in the permanent, the search for individual differentiation: fashion is born of the 35 combination of the two needs, it is "the imitation of a single exemplum and

27 Volli, Block Modes, 9.

28 Simmel, "Fashion," 542-543. 
satisfies the demand for social adaptation," through the rapid change of its 1 content, but on the other hand, it authoritatively imposes itself, "because fashions differ for different classes - the fashions of the upper stratum of society are never identical with those of the lower; in fact they are abandoned by the former as soon as the latter prepares to appropriate them."29

So, fashion represents "nothing more than one of the many forms of life by the aid of which we seek to combine in uniform spheres of activity the tendency toward social equalization with the desire for differentiation and change."30 Another form in which different needs for stability and innovation are equally expressed is certainly law, where the state position of the legisla- 10 tion goes hand in hand with an innovative interpretation of the same according to specific dynamics, but also, in previous eras, where the laws considered a natural right and custom cohabit with the newness present in laws validly imposed by the state. It could therefore be said that also law, like fashion, could cease to be a social phenomenon, ceding its role to other institutional 15 systems, just as today the economy or technology seem to occupy its place. Volli asks himself precisely these questions at the moment of the end of fashion, with the emergence of the postmodern, as we will see. However, he asks this not before he has explained how for Simmel, "two social tendencies are essential to the establishment of fashion, namely the need of union on the 20 one hand and the need of isolation on the other." In the case where one of the two is absent, "fashion will not be formed - its sway abruptly end", 31 he notes. At the same time, fashions can always be traced to the differences in social class and "just as soon as the lower classes begin to copy their style, thereby crossing the line of demarcation the upper classes have drawn and destroying 25 the uniformity of their coherence, the upper classes turn away from this style and adopt a new one, which in its turn differentiates them from the masses; and thus the game goes merrily on."32

Once again, the theory of the elites and the distinction between "types of man" that Simmel ascribes to the phenomenon of fashion is central also in 30 determining the development of law in the second millennium. The same historiographical theory that sees the antecedents of the state in the Middle Ages in fact indicates that there is a constant structure that differentiates "clerics and lay people", in relation to a greater proximity of the former to

29 Simmel, "Fashion," 543.

30 Simmel, "Fashion," 543.

31 Simmel, "Fashion," 546.

32 Simmel, "Fashion," 545. 
the ideal "third" of the (imaginary) foundation of power. ${ }^{33}$ The greater close- 1 ness of the clerics to the source of power and law (in the Middle Ages, God) represents a structure of government - or of influence over the masses - which extends to the distinction between classes in differing systems of religion, in the first place in the modern state (which distinguishes between state bureau- 5 cracy and the citizens) and in politics (the members of the party and the citizens/subjects) but it also extends to other systems such as the multinationals (the division between management and workers) to scientific and technological knowledge (the "experts" and the citizens) to fashion (the stylists and the masses), as Simmel points out, and to communication (VIPs and 10 television viewers). ${ }^{34}$

Pursuing the analysis of Simmel, Volli and the historical-juridical contributions, between the history of law and the analysis of the phenomenon of fashion there is therefore the constancy of a structure of change that maintains the reference to the distinction between two classes that seem to want to differenti- 15 ate themselves and yet copy each other, to the point where they see the dissolution of this structure (end of fashion - of its system of imitation, end of law - of its system of sources). ${ }^{35}$

We have just stated that this dynamic of change identified in such different systems as law, politics, economics, communication, science and fashion is a set 20 of governmental structures and a way of influencing the behaviour of the masses. In fact, in law we observe the two populations to which it applies: the demos, the population united in a deliberative function, and the laos (from which the term "layman" is derived) that is to say the people gathered in a liturgical form. In this way it is possible to note that there has never been a society that was governed only 25 through laws and rationality, rituals, games, music and ceremonies have always played their part, ${ }^{36}$ and all this belongs to the sphere of the rational. In other words, the juridical (the dogmatic) necessarily has an aesthetic veneer. ${ }^{37}$

33 With reference to the Decree issued by Gratian, Pierre Legendre, Leçons VI. Le Désir Politique de Dieu. Étude sur les montages de l'État de Droit (Paris: Fayard, 2005), 80-82; Corpus Iuris Canonici Decretum Magistri Gratiani Secunda Pars, Quest. I. c. VII Clericis et Deo deuotis nec causas agere, nec aliquid proprium habere licet; with reference to the Canon of Pope Gelasio, "Duo sunt Quippe," Legendre, Leçons IX. L'Autre Bible de l'Occident, 303-310, Corpus Iuris Canonici, Decretum Magistri Gratiani Prima Pars Dist. XCVI, c. 10 Item Gelasius Papa Atanasio Inperatori.

34 For this scheme see Paolo Heritier, Estetica Giuridica (Torino: Giappichelli, 2012), vol. II, 148. 35 Alberto Andronico, Viaggio al termine del diritto. Saggio sulla Governance (Torino: Giappichelli, 2012).

36 Pierre Legendre, Leçons II. L’Empire de la Vérité. Introduction aux Espaces Dogmatiques Industriels (Paris: Fayard, 1983), 61-64.

37 Heritier, Estetica Giuridica. 
Similarly, the abrupt change in fashions is not only a characteristic referred 1 to the irrationality of the changes in taste and in the forms of dressing, but contains in itself, through the reference to the dynamics of the division of society into the classes that belong to each civilization, a normative element: in this sense it is, so to speak, the exact opposite of the governance in a constant 5 structure (an element that refers back to Lotman's semiotic theory).

Independently from this way of presenting the problem that we have identified, another common element, starting from Simmel's analysis, between fashion and law, is that fashion possesses "this peculiar quality, that every individual type to a certain extent makes its appearance as though it intended 10 to live forever." 38 This is a trait also found in the specificity of law, where every law, if it is to be defined as such, presents itself as potentially eternal, even though all the interpreters (judges, lawyers, bureaucrats) understand that it is subject to an inevitable future change, independently of the concept of law that supports it (whether jusnaturalist, consuetudinary or juspositivist). The principle 15 of natural law is by definition eternal, although everyone knows that there have been infinite historical versions of natural law. Thus, the principle of positive law is applied by judges as if it should never change (at the time when they apply it they must functionally believe that it will not change) yet they know perfectly well that new jurisprudential interpretations will certainly intervene in 20 the near future, and that these will certainly be altered by the same legislator at some time. This introduces the fictional characteristic of law, its belonging to Lotman's semiosphere, to the mythical third plane of the foundation for Legendre, or as I prefer to call it, World 0. If it did not pursue this fiction, no law could ever be applied with effectiveness, in effect reducing law to a calcula- 25 tion concerning the future changes to the interpretations of a law and continually postponing a further moment of decision.

This is also the difference that exists between the historical and the literary interpretation of the text (always susceptible to being altered by successive interpretations) and the juridical interpretation, which must decide the case on 30 the basis of the state of the documents, without having the opportunity, except in rare cases, to return to the question decided (what is known as the theory of res iudicata or claim preclusion). To say, as Volli does, that fashion is a victim of postmodernity thus introduces the comparison between fashion and law, in

38 Simmel, "Fashion," 556. On Simmel also Carter, Fashion Classics, 59-82 and Edwards, Fashion in Focus, 17-19, who points out that Simmel's exceptionable and reversible theory "sometimes known as the 'trickle-down' theory, also starts to set up the parameters for much succeeding discussions of style and fashion," 17. 
which, as we have observed, postmodernity has implied the application of the 1 juspositivist paradigm. If it has ever represented an exhaustive explanation of the phenomenon of fashion, ${ }^{39}$ the so-called trickle-down theory presented by Simmel certainly appears to have been overtaken by the establishment of a plurality of styles in which the phenomenon of fashion is replaced by increas- 5 ingly multiple, confused styles, rich with citations and ambiguity: in other words in the direction of a complex model of interaction between classes that cannot be summarised in the concepts of differentiation and imitation. Volli analyses this point very precisely, noting how the traditional sociological model of explanation of fashion interprets communication as a simple passage of infor- 10 mation, dominated by imitation:

The first and most simple explanatory model is the drop model which imagines a society similar to a pyramid where fashions derive from the top by "dripping”: at the "apex" of society for some reason a rule of taste is imposed and the social mass gradually adapts to it, adaptation that progresses from the top to the bottom. When the elite realises that its tastes have been assimilated to the point where it has become similar to the masses, it invents a new rule to differentiate itself. And so on. The idea is that there exists a sort of dynamic impulse of creation which is perceived by the social body through imitation. Differentiation and imitation work together to produce Fashion. If ever things used to happen in this way, today, in a complex and competitive society, this idea seems excessively simplistic. Nowadays society cannot be structured in pyramidal terms; we live in an essentially complex environment and the places of other social visibility are the powerless elites, the stars of cinema, theatre, television and sport. With respect to haute couture, prêt a porter, designed for much larger numbers, has gained first economic and secondly cultural prestige. Nowadays the most plausible model for fashion is contagion. Fashions start from impulses that can be born anywhere. Each of us, adapting to a certain fad or a given trend allows it to win or lose, in a sort of constant voting. The communicative mechanism in play is therefore much more complicated. In effect it is a form of fascination, in which expressive functions, conventionality, connotative and seductive capacity all interact. The communicative mechanism within fashion is after all very similar to the use that the consumer makes of their garments. There are many instruments for this communication: fashion shows, advertising, specialist press, and so on. All these tools are however limited by the nature of their centralised transmission, without feedback, organised according to the model of broadcasting, and characterised by non-interactive means of communication such as radio and television. It is more realistic to think that the network models also operate in fashion, where trends are transmitted horizontally, by word of mouth or by visual imitation, also the influence of the mass media continues to be very important. $^{40}$

39 As Edwards also believes, the criticism of the "trickle-down theory" is based on the fact that "styles may equally trickle up as well as down and that lower or working class groups may in particular seek to reach against rather dumbly follow dominant patterns, primarily via more subcultural styles and consumption practices." Edwards, Fashion in Focus, 17.

40 Volli, Block Modes, 7-8. 
We have included this lengthy and conclusive quotation on the semiotic 1 analysis and criticism of the traditional sociological analysis precisely because it clearly introduces a theoretical modularity into the analysis of phenomena of law and fashion, already introduced thanks to a series of analogies. We have mentioned how in the juridical sphere the traditional, pyramidal juspositivist 5 model (Kelsenian) of the sources is being replaced by a reticular conception of law, in close relation to the emergence of phenomena such as soft-law, ${ }^{41}$ governance $^{42}$ and, more generally, a theory of the network of the law, ${ }^{43}$ which precisely overlays, from the epistemological point of view, the network models described by Volli with regard to the passage from "modern" fashion to post- 10 modern styles.

\section{Towards a juridical vision of fashion}

It is not, nevertheless, towards the analysis of a specific system of communication of postmodern fashion - in its differences from modernity - that we want to move, a task already carried out by the semiotic analyses of Volli and other scholars from various disciplines specifically dedicated to it.

We are, instead, interested in understanding the impossibility of reducing the analysis of the normativity of the phenomena of fashion, of their devices of social and class-driven "obligatoriness" with regard to individual behaviour. The phenomena cannot be explained without an adequate consideration of juridical knowledge, or by merely undertaking a psychological, sociological or political 25 analysis of human behaviour. The question of fashion appears to be a truly

41 For a classic definition of soft-law: "rules of conduct that are laid down in instruments which have not been attributed juridically binding force as such, but nevertheless may have 30 certain (indirect) juridical effects, and that are aimed at and may produce practical effects." Linda Senden, Soft-Law in European Community Law (Oxford, Portland: Hart, 2004), 112.

42 Wer use here the Renate Mayntz's definition of governance: “a new style of government, different from the model of hierarchical control and characterised by a greater degree of cooperation and interaction between the state and the non-governmental players within the mixed public/private decision-making networks." Renate Mayntz, "La teoria della Governance: 35

Q3 Sfide e Prospettive,” Rivista italiana di Scienza Politica 1.3 (1999). See also Andronico, Viaggio al termine del Diritto. Saggio sulla Governance; Jacques Lenoble and Marc Maesschalck, Toward Theory of Governance. The Action of Norms (The Hague-London-New York: Kluwer, 2003).

43 Paolo Heritier, Urbe-Internet. La Rete Figurale del Diritto (Torino: Giappichelli, 2003); François Ost, Michel van de Kerchove, De la pyramide au Réseau? Pour une Théorie Dialectique du Droit (Brussels, Publications del Facultés Universitaire, 2002). 
institutional phenomenon, in the sense in which Legendre, for example, speaks 1 of dance ${ }^{44}$ and liturgy ${ }^{45}$ as institutional phenomena, relating to the government of the laos using means other than mere positive law, as previously indicated. This is a position that entails a perception of law not seen as merely posed by a legislator or simply ascribable to an ethic preceding law (from Kant to 5 Dworkin). ${ }^{46}$ For example, in Kant, the ethical setting of the brief analysis of the question of fashion is clear. After having indicated the way in which the question of taste has an intrinsically ethical value, he states that fashion "is not properly a matter of taste [...] but a matter of mere vanity in order to appear distinguished."47

The Kantian vision is not without interest, because it seems to grasp the original connection of the phenomenon of fashion with ethics and law, but its formalism prevents a correct understanding of the question: the philosopher of the Critiques identifies the matrix of fashion as originating in imitation, seen as a natural tendency of man, for whom fashion represents a law, which only 15 apparently belongs to taste - since anyone who is unfashionable is outdated and anyone who does not consider being unfashionable important is eccentric but in effect, since it separates taste from morality, it is folly, because it sacrifices duty to vanity. ${ }^{48}$ This vision, dominated by ethics, does not mean that its analysis neglects noticing important elements precisely where it con- 20 nects fashion to usage - opening a topic, the connection between fashion and custom, which we on the one hand constitutes the true object of criticism, but at the same time appears impossible to delineate here - and it is characterised by linking it to a passion for the new:

44 See Pierre Legendre, La Passion d'être un Autre. Étude pour la Danse (Paris: Seuil, 2000). 45 For an examination of the notion of juridical liturgy see: Paolo Heritier, "Law and Image: Towards a Theory of Nomograms," in Law, Culture and Visual Studies, Vol. 1, eds. Anne Wagner and Richard Sherwin (Dordrecht, Heidelberg, New York, London: Springer, 2014), 25-48; Paolo Heritier, Estetica Giuridica, Vol. 1 Dalla Globalizzazione alla Secolarizzazione and Vol. 2 A partire 30 da Legendre. Il Fondamento Funzionale del Diritto Positivo (Torino: Giappichelli, 2012).

46 For an aesthetic criticism of the presumed objectivistic naturalism of Dworkin see: Peter Goodrich, "Devising Law: On the Philosophy of Legal Emblems," in Law, Culture and Visual Studies, Vol. 1, eds. Anne Wagner and Richard K. Scherwin (Berlin: Springer, 2013), 3-24.

47 Immanuel Kant, Anthropology from a Pragmatic Point of View [1798], trans. Victor Dowell (Edwardsville, IL: Southern Illinois University Press, 1996), 148.

48 "It is a natural inclination of man to compare his behaviour to that of a more important person (the child compares itself to grown-ups, and the lowly compares himself to the aristocrat) in order to imitate the other person's ways. A law of such imitation, which aims at not appearing less important than others, especially when no regard is paid to gaining any profit from it, is called fashion. Therefore it belongs under the title of vanity, because in its intention there is no inner value.” From Kant, Anthropology from a Pragmatic Point of View, 148. 
"All fashions are, by their very concept, mutable ways of living. Whenever 1 the play of imitating becomes fixed, imitation becomes usage, and that means the end of taste. Novelty makes fashion alluring [...]." ${ }^{49}$ It is not, however, the ethical view that can explain the normativity of the fashion system, and neither can the political view or gender studies, as seems clear from the analysis by Parkins 5 who, in analysing the protest of the female members of parliament regarding a controversial Italian judgement, ${ }^{50}$ indicates the way gender-based political protest can be read as "attempts to refashion the body politic through drawing attention to the significate - and the signification - of dress in political contexts," and it can be linked to the principle objective of research aimed at showing "how forms or items

49 Kant, Anthropology from a Pragmatic Point of View, 148.

50 It is in fact a sentence handed down by the Italian Court of Cassation (Cass. Pen., III sezione, n. 1636/99) which, according to Parkins - writing in the period immediately subsequent to the sentence following a protest by the female components of the Italian parliament and in California - established the incompatibility between the wearing of jeans and sexual violence, as if it were possible to juridically identify a relationship between a garment and the consent to rape. In the sentence the passage was one point in a more complex reasoning, in which the use of this argument, decontextualized, caused considerable consternation in the media, moreover, misunderstanding the complex reasoning, as the Court of Cassation recognised in successive sentences clarifying this point. The sentence of 1999 had, in fact, annulled with recommitment to the Court of Naples, the decision of the Appeals Court of Potenza, which considered the defendant guilty of rape without taking into account the presumed fact of common experience according to which it is almost impossible to undress, even partially, a person wearing jeans, without their effective collaboration, because it is already a difficult task for the person wearing them (but the recommitment was made on the basis of many other considerations, although public opinion reduced the entire question to this sole declaration from the discourse). The Court of Criminal Cassation Section III later returned repeatedly to this odd question, and in the sentences numbers 13070/99, 22049/06, 40542707 and 30403/08 completely clarified the equivocations regarding the question of clothing. This criticism does not, of course, mean that we intend to defend the indefensible position of the Court of Cassation of the 1999 sentence, in not having recognised according to Parkins, "the physical violation at the centre of the case before them and gestured towards the implications for all women when an item of clothing alone is construed to signify consent”. Wendy Parkins, ed., Fashioning the Body Politic. Dress, Gender, Citizenship (Oxford, New York: Berg, 2002), 2. Quite apart from the inevitable media exploitation, Parkins' considerations on such a dramatic and delicate question are essentially valid, nevertheless, we feel that the political or gender view of the matter is not the most useful - not 35 more useful than the Kantian ethical one - in understanding the juridical problem of the normativity of fashion as writing on the body, placing itself only as the deconstructionist overturning of the Kantian ethical model (in fact, we must not forget that Foucault wrote his theory, which later became the well-known text on "Les Mots et les Choses," as the antithesis of Kantian anthropology, which he translated in parallel to the writing of what has become a sort of Bible for political and gender criticism). 
of dress - from the ceremonial to the everyday - can themselves become sites of 1 political struggle, how they can be used variously to contest or legitimate the power of the state and the meanings of citizenship." 51

The foucaultian topic of the political nature of the body in understanding the phenomenon of fashion advanced by Parkins is also considered, with 5 specific reference to the topic of fashion, by Entwistle, who emphasises the importance of the corporality of fashion, in criticising the usual analyses of fashion guilty of having neglected this essential aspect:

fashion is about bodies: it is produced, promoted and worn by bodies. It is the body that fashion speaks to [...] when we speak of fashion we speak simultaneously of a number of overlapping and interconnecting bodies involved in the production and promotion of dress as well as the actions of individuals acting on their bodies when "getting dressed." 52

Svendsen also identifies the importance of the practices of fashion for the configuration of the body and of the identity, noting how, "The shaping of 15 self-identity in the postmodern era is in a crucial sense a body project [...] The ego is very much constituted via the presentation of the body." 53 While these authors identify the central topic of the question of fashion - corporality - what they do not explain is the juridical basis of its theory: the fact that the question of politicality (and the functionality) of the body is rooted in the tradition of the 20 Corpus Iuris (Civilis and Canonici) of the Western, Roman and Medieval traditions. The question of the relevance of clothing in the history and the theory of law is picked up by Migliorino, who places on the frontispiece of his work Il corpo come Testo. Storie del diritto ${ }^{54}$ [The body as a text. Histories of law] the well-known image of the ancient, patched felt garment, hanging on a coat 25 hanger, without a body, ready for any number of other bodies, that Beuys recalled in his fall from a plane in Russia (and his being saved by loving though unexpected care) during the second World War. ${ }^{55}$ That husk of the person, that garment without a body became the symbol of the fictiousness of law in a book that intended to seek a "declination of the body that, from the surface of the 30 writing, becomes instead the writing of a text, rather, an open space, as the place of existence," ${ }^{26}$ a hypertextual plot that combines such diverse juridical

51 Parkins, Fashioning the Body Politic, 2.

52 Joanne Entwistle, The Fashioned Body. Fashion, Dress and Modern Social Theory (Cambridge: Polity, 2000), 1-2. See also Edwards, Fashion in Focus, 42.

53 Lars Svendsen, Fashion. A Philosophy (London: Cromwell, 2006), 75.

54 Francesco Migliorino, Il Corpo come Testo. Storie del Diritto (Torino: Bollati Boringhieri, 2008).

55 Jacob Beuys, Felt Suit (London: Tate Modern, 1970).

56 Migliorino, Il Corpo come Testo, 9-10. 
notions as obedience, conscience, sign, simulation, body, rule, identity and 1 many others, but also fashion and custom, against the background of an admirable "theophany of the medieval universe with its cathedrals of ideas sought and ordered by a cybernetic God and the amazing play of masks that law presents before an audience of men left children."57

The previous reference to Volli's brief citation of the medieval and premodern roots of fashion can at this point be substituted by a precise and somewhat complex historiographical theory, whose roots are to be found in the masterly work by Kantorowicz, which identifies the Christian roots of the theory of the two bodies of the King, of which we will follow some reconstructions relating to 10 the notion of body politic. ${ }^{58}$ This is a topic that leads us to analyse in this article the juridical knowledge of the body, the medieval tradition of the Corpus Iuris and the fictionality of the notion of the juridical person, ${ }^{59}$ topics central to a juridical theory of fashion as an institution.

In fact, Kantorowicz points out that the concept of the Church as Corpus 15 Mysticum dates from the Pauline epistles and shows how, nevertheless, it acquired importance only in the Carolingian era in relation to a controversy over the Eucharist between Pascasius Radpertus and Ratramnus, in which the latter, on the basis of the authority of Hrabanus Maurus, observed that "the body in which Christ had suffered was his 'proper and true body' (proprium et verum 20 corpus) whereas the Eucharist was his corpus mysticum."60 In the sphere of dogma and liturgy, therefore, originated "that notion whose universal bearings and final effects cannot easily be overrated:" the notion of a corpus mysticum, that originally and for many centuries did not refer to the unity of the Church, but to the Eucharist. Only following the controversy on the transubstantiation, 25 after 1150, did the notion of the corpus mysticum abandon its liturgical sense to mean solely the Church as the organised body of Christian society united by the sacrament. It assumed "a connotation of sociological content,"61 allowing for the secularization of the term that followed, linked to the investiture controversy. The new meaning of the term sanctified the corpus mysticum iuridicum, 30 the juridical and economic administration of the Church, linking the visible Church to the Eucharistic liturgy. At the same time, however, it placed the Church "as a body politic, or as a political and juridical organism, on a level with the secular bodies politic which were then beginning to assert themselves

57 Migliorino, Il Corpo come Testo, 10.

58 Kantorowicz, The King's Two Bodies.

59 Heritier, Estetica Giuridica vol. 2, 71-85; Legendre, Leçons II, L'Empire de la Vérité.

60 Kantorowicz, The King's Two Bodies, 195.

61 Kantorowicz, The King’s Two Bodies, 196. 
as self-sufficient entities."62 The proclamation of the Church as corpus mysticum 1 was then echoed, according to Kantorowicz, by the self-proclamation of lay and imperial power as the Holy Empire, around the mid-twelfth century. With Simon of Tournai, in 1165, the body of Christ was thus thematised in two senses that were no longer connected to the human and divine nature of Christ, but as his 5 material and individual body and the spiritual and collective body, stepping back from the theological discourse. In the question of the duplex corpus Christi - corpus naturale and corpus mysticum or figuratum - Kantorowicz recognises "the precise precedent of the "King's two Bodies'."63

A central passage of this process is the rationalising work by Thomas 10 Aquinas. In fact, for Aquinas, the natural body of Christ does not indicate the Eucharist, but His physical body, to be seen as "an organism acquiring social and corporational functions." ${ }^{44}$ At the same time Thomas began to indicate the notion of corpus mysticum as corpus ecclesiae mysticum and not only as corpus christi mysticum: beginning a process of autonomisation of the mystical eccle- 15 siastical body that Kantorowicz considered "just another step in the direction of allowing the clerical corporational institution of the corpus ecclesiae iuridicum to coincide with the corpus ecclesiae mysticum and thereby to 'secularize' the notion of 'mystical body.",65 The transposition suggested by Thomas Aquinas in this sense is rather interesting, since it appears to be linked to the substitution 20 of a liturgical language with the juridical one He alters the notion of corpus to persona, ${ }^{66}$ a notion that Kantorowicz considered essential in this complex process of linguistic and conceptual transpositions from which the idea of the political nature of the body derives. Moving from the notion of a mystical person to that of a fictional person (persona rapraesentata or ficta), in fact becomes an 25 important characteristic of the political theory of the late Middle Ages, an element that highlights a transposition from the liturgical to the political, and which, moving from the distinction between the demos and the laos previously mentioned, confirms the emergence of the political from the liturgical. Around the entourage of Pope Boniface VIII in particular, notes Kantorowicz, 30 "Undeniably the former liturgical concept of corpus mysticum faded away only to be transformed into a relatively colourless sociological, organological, or

62 Kantorowicz, The King’s Two Bodies, 197.

63 Kantorowicz, The King's Two Bodies, 199.

64 Kantorowicz, The King's Two Bodies, 201.

65 Kantorowicz, The King's Two Bodies, 201.

66 Aquinas, Summa Theologica, III q. VIII, a. I: "Dicendum quod caput et membra sunt quasi una persona mysticai" and in numerous other places in the Summa. 
juristic notion." 67 The Pope, indeed, in the context of the progressive emergence 1 of his imperial power borrowed from the Roman Emperor, ${ }^{68}$ could be considered the head of the mystical body of the Church more easily than he could be considered the head of the mystical body of Christ, but this perspective opened a somewhat significant consequence that would appear at a later date. 5 Without further delving into the internal events of the progressive reorganisation of the Church during the early years of the second millennium, we must note that the process is important for the emergence of the notion of the body of the state starting from the notion of the body of the Church, against the background of the relationship between the Corpus Iuris Civilis and the Corpus Iuris Canonici. Conclusively, follow- 10 ing the analysis by the historian, in fact the concept of corpus mysticum, "after having lost much of its transcendental meaning and having been politicized and, in many respects, secularized by the Church itself, easily fell prey to the world of thought of statesmen, jurists, and scholars who were developing new ideologies for the nascent territorial and secular states." ${ }^{69}$ Thus there emerges the well-known 15 contraposition between unum corpus reipublicae and unum corpus ecclesiae in the context of the investiture controversy and of the contraposition of the Holy Roman Empire of the Middle Ages and the temporal power of the church, of which Kantorowicz identifies the origins in a rising process, culminating in the substitution by Thomas Aquinas of the theological notion of the corpus mysticum with the 20 persona mystica, a notion close to the juridical notion of persona ficta.

From this complex historical-juridical analysis emerges an interesting point for the analysis of fashion as an institution: that is to say, as we will see with Legendre, the value of the notion of corpus mysticum used in other senses, and referred to a political context that continues to be liturgical and ritual, in which 25 his reference to the idea of the body:

was used synonymously with corpus fictum, corpus imaginatum, corpus repraesentatum, and the like - that is, as a description of the juristic person or corporation. The jurists, thereby, arrived, like the theologians, at a distinction between corpus verum - the tangible body of an individual person - and corpus fictum, the corporate collective which was intangibile and existed only as a fiction of jurisprudence. ${ }^{70}$

67 Kantorowicz, The King's Two Bodies, 202.

68 The theoretical interpretation of the emergence of the "imperial" role of the Roman pontefice and therefore the connection between the Corpus Iuris Civilis and the Corpus Iuris Canonici, is to be found in Legendre, La pénétration du droit romain dans le droit canonique classique de Gratien a Innocent IV (1140-1254) and in Legendre, Leçons IX. L'Autre Bible de l'Occident.

69 Kantorowicz, The King's Two Bodies, 207.

70 Kantorowicz, The King's Two Bodies, 211-212. 
In analogy with the theological language, therefore, the jurists began to use the 1 juridical notion of the fictitious person as a mystical body: as Kantorowicz further reveals a late medieval jurist like Antonius de Rosellis, in the fourteenth century, could list five corpora mistica of human society: village, town, province, kingdom and world. 71

The reference to the idea of the political body thus passes from the Corpus Iuris Civilis of medieval canonical law, seen as texts that refer to the idea of a body (the laos, the people united by the liturgy), to the modern aesthetic signification (functional and iconic) of the notion of the political body, referring to the modern state, which is still to be found on the well-known frontis- 10 piece of Hobbes' book Leviathan (see Figure 1).

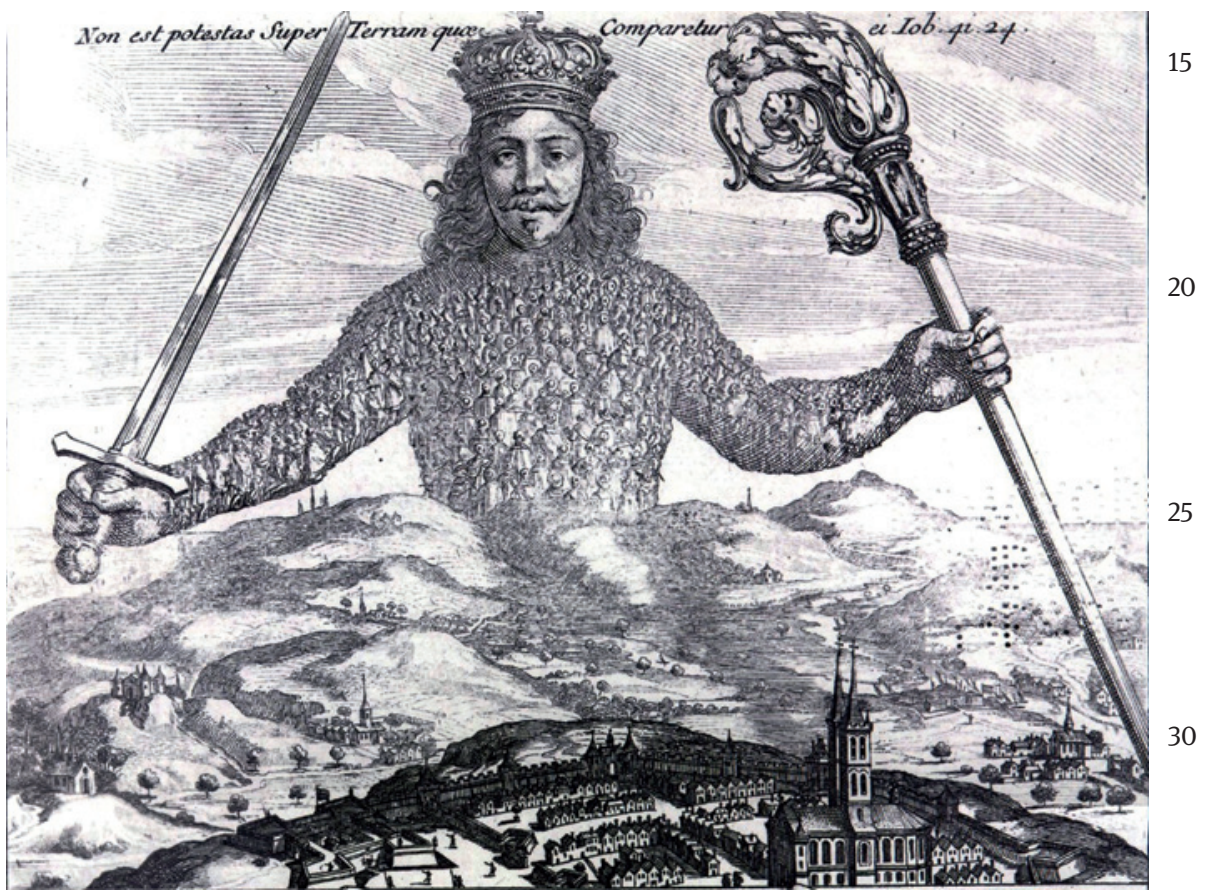

Figure 1: Frontispiece of Hobbes' book Leviathan (1651). 
It is an emblem that shows the state as the body of the biblical monster 1 Leviathan, taken from the Book of Job, ${ }^{72}$ as a fictitious person composed of many men, who form him and continue to maintain this ambiguity of value between the mystical body and the political body, between the mystical body and the ethical and political value of the state, which we will later find in the icono- 5 graphy of totalitarianism, as Falasca-Zamponi points out, presenting the image of the political body of Mussolini (see Figure 2.) ${ }^{73}$

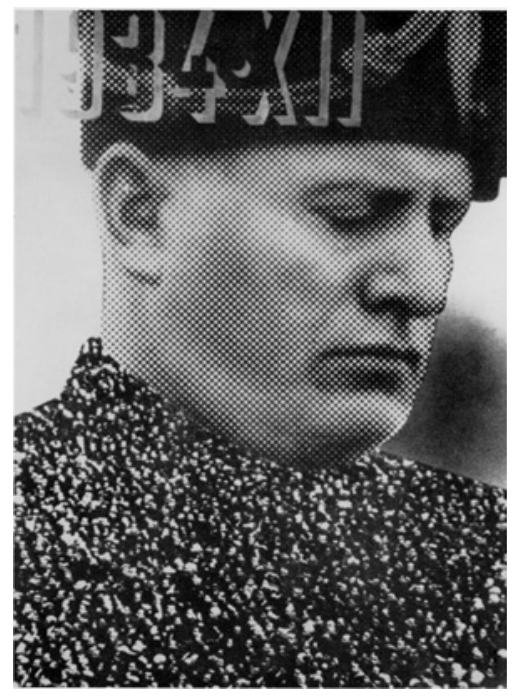

Figure 2: Benito Mussolini.

72 As shown in the emblem of the frontispiece of the Leviathan: "Non est potestas super terram 30 quae comparetur ei” (Iob., 41.24). On Hobbes, see Julián Jiménez Hefferman, "Corpus Delicti: The Evidence of the Body as Body of Evidence in Thomas Hobbes's Political Imagination," Polemos 6.2 (2012): 293-317. However, see also, the reference to the body of the Leviathan (and Behemoth) in the well-known chapter on the subject by John of Salisbury, Polycraticus (VI, 1), in Patrologia Latina, CXCIX, coll. 589-592.

73 Simonetta Falasca-Zamponi, "Peeking Under the Black Shirt: Italian Fascism’s Disembodied 35 Bodies,” in Fashioning the Body Politic: Dress, Body, Citizenship, ed. Wendy Parkins (Oxford: Berg, 2002), 145-166. The image, from Falasca-Zamponi, "Peeking Under the Black Shirt," 163. As the author states: "Fascism's vision of its citizenry was that of a disembodied whole phagocitated by the body of the dictator," Falasca Zamponi, "Peeking Under the Black Shirt," 164. See also Simonetta Falasca-Zamponi, The Aesthetics of Power in Mussolini's Italy (Berkeley, CA, Los Angeles, London: University of California Press, 1997). 
The theory that we want to present here is precisely the importance of this 1 historical-juridical question of the mystical body and the juridical person with the analysis of the representation of the body of fashion, to which Parkins, Entwistle and Svendsen previously referred. The aesthetic value of this division between body politic and mystical body has a liturgical and aesthetic value, and 5 continues to secularise itself: the institutional function of fashion in modernity cannot be understood if we neglect to indicate the origin of the distinction between corpus mysticum, persona ficta and corpus politicum seeking only the origin in the cult of the body of the dictator which characterized twentiethcentury totalitarianisms. The body that fashion dresses is the last offshoot of this 10 notion of mystical body, secularised first in a political sense, then in an aesthetic sense. The body dressed by the fashion of modernity is a body that maintains a secularised liturgical meaning, and at the same time a political dimension combined with its aesthetic dimension.

The analysis of the Legendrian theory of fashion will confirm this research 15 hypothesis.

\section{The personae fictae of fashion: notes on the institutional theory of Legendre}

The conclusion of this article is therefore the proposal to reintroduce the secularised juridical and theological lexis for the aesthetic comprehension of 25 the relationship between the natural body and the fictitious body, seen as a mystical and political body, and considered present in the practices of dressing and twentieth-century fashion. It is of course more a research programme than a fully-developed theory.

We can indicate, for example, the way the stylised bodies of the models in a 30 fashion show speak as persona ficta to the liturgical collective gathered in institutionalised rituals, intended to keep a society aesthetically together through a normativity that tries to impose itself socially, indicating an élite - and consequently the behaviour and aesthetic-dogmatic models for the masses to follow, through the logic of imitation - even though we have seen with Volli how this 35 scheme is severely affected by postmodernity.

Recently the French juridical historian Pierre Legendre, already the author in the 1980s of an essay on dance as a form of writing - that is to say "a ceremony of transformation of the body into text" as a discourse of law, as a 
body without voice that speaks ${ }^{74}$ directly took into account the problem of the 1 juridical nature of fashion. ${ }^{75}$ Let us therefore conclusively analyse, in a fairly simple manner the thinking, which is instead very complex, of the French juridical historian. Legendre, analysing the term of fashion in a rather classical manner, begins from two propositions of fashion almost taken for granted:

- the way fashion establishes "the socially defined but temporary,"76 the precarious but creative moment of a $\delta o ́ \xi \alpha$ in matters of clothing;

- the way fashion belongs to the world of management and industrial production, inasmuch as it is a system of signals imposed/proposed by the clientele.

The most banal element that he identifies is instead the normative extent of the display (ostendere) characteristic of fashion, which refers back to an ultramodern system of signals of the market to its institutional roots, to the aesthetic mystery that governs the institutions. The stage of fashion, the construction of 15 the bodies of the models in a fashion show, seen as an anthropological rite of Western and globalised societies, clearly indicates the primordial root of the institutions, which suggest a "dematerialisation of the materiality of the body" and the construction of an ideal object in a minimalist theatre in which the basic human fiction, the embrace of the body and its image performs."77 In order to 20 understand the institutional nature of fashion he refers, nonetheless, not to the catwalk, but to the construction of an inert object, the shop mannequin, an object designed to be similar to the human body by means of a process of standardisation, of construction of a theatrical and fictional character - the lay heir of the persona ficta we could add - equipped with the function of "representing a standardised mirror image in the industrial age - in some way a cadaver of the image, that is resuscitated by the gaze of a subject, the gaze of the stylist and the gaze of the passer-by, in the perspective of serving the aesthetic interrogation of the forms, of feeding the insatiable curiosity of the anonymous public, of stirring the interests of commerce." ${ }^{\text {78 }}$ The metaphysical question that 30

74 Legendre, La passion d'être un autre, 9. Legendre says, "there is nothing more juridical than dance, which enacts the idea of the most abstract law and which was the most difficult to formulate in the science of Western jurists, that is to say the idea itself of representation- 35 impersonation. Another speaks for me, represents me and what he says is still me” My trans. 75 Pierre Legendre, “Conclusion générale. Une métaphore de l'institutionnalité: la Mode,” in Argumenta Dogmatica. Le Fiduciaire suive de Le Silence des Mots (Paris: Fayard, 2012).

76 Legendre, Argumenta Dogmatica, 136 [my translation].

77 Legendre, Argumenta Dogmatica, 138 [my translation].

78 Legendre, Argumenta Dogmatica, 139 [my translation]. 
lies behind this appearance is represented by the power of the mannequin as $a 1$ material object deprived of every psychic element, reduced to a mere material object representing the human. Thus, there emerges another form of the process of dematerialisation of the body and of reality, already indicated with regard to the language and the distinction between the word and the thing, the fashion: 5 a non-verbal manner, however, that calls up the question of identity, on an individual and collective plane.

So, fashion, like all contemporary arts, touches on the question of who we are, but according to specific modalities, such as the ceremonially instituted relationship, concerning the commercialisation of the dark and ideal place of the 10 venerated ancestral images, of the myth and the ideal construction of the Ego. Mobilising desire, fashion is one of the forms through which the human being constructs a "second body", fictitious, represented, parallel to the real body, which is constitutive of the subjective and collective identity of a society. This body is fashioned under the ritualised and institutionalised form of the garment 15 that hides a body, concealing its animality, which gives access to a collective fictitious reality, of which, we could add, all the products of the semiosphere, including the juridical institutions, are formed. Fashion, then is the revival of the infinitely belaboured question of aesthetics: the habitat of a body that perceives itself as If, ${ }^{79}$ as if the body were not the body: in the manner of its demater- 20 ialisation. Fashion therefore takes its place amongst the institutions as a form of thirdness, on the fictitious plane - just as the fictitious image of Hobbes' Leviathan is representative of the modern fictitious and constructed state. Or precisely as the notion of persona ficta represents the medieval corporation, inasmuch as it is a form of fictitious body through which we theatrically intuit 25 social and normative practices concerning the subjective and collective identity, aimed at the mobilisation of causing to believe in the (existence of) the institution as a body politic and aesthetic. As Legendre states, the body-model recreated by the design, dematerialised as the word, becomes the stage-model for the constitution of the subject through the rhetoric that the garment itself enacts. 30 It passes through the third place of the mirror image of self that presides over the dominion of the registers of identity and the otherness of the subject (individual and political), the plane that Lotman would call the semiosphere, but which here is read in a juridical key: the fictitious and aesthetic foundation of the institutions that speak to the laos - the people gathered in liturgical 35

79 The central theme for the construction of the notion of juridical person, from the fictio iuris elaborated by the Roman jurists, to Innocenzo IV, and up to Kelsen, Heritier, Estetica Giuridica, Vol. 2. 
function to obtain obedience. It is the image of the body in which the institu- 1 tions are incarnated, the corpus iuris, as a phenomenon that can be observed in all societies, and not only in totalitarian states.

In this sense, and with these precise limits, "we can say that fashion belongs to the institutional chain: while it depends on the fiduciary register, it is at the 5 same time connected to the social system of norms (in particular juridical) as a whole." 80 Fashion, like other aesthetic dimensions, makes us believe in the reality of the body as something not exclusively animal and in this sense belongs to the world of the institutions, which make us believe in the reality of an ideal and mythical plane - the place of the origin of power - which is not real, but 10 constructed, artificial, fictitious, without passing for that which it is not - and which has never been seen to govern any society. The plan of instituting the cause to believe is the secularised plan to which fashion gains access, taking - in part - the place of the mystical, represented, fictitious body of the Western tradition of the Corpus Iuris and of the state, in an institutional context already 15 placed beyond the sovereign state symbolised by Hobbes' Leviathan and by the totalitarianisms of the twentieth-century. Thus we can explain why the fashion of making-up, disguising and transforming the body is the characteristic of fashion, which has to recreate a different body from the natural one, a second, constructed, fictitious, mythical body, a space in which it tries to impose normative 20 consequences, and, thus, standardised behaviour. Fashion tries to produce identification, to cause us to believe in the existence of an order, of classes of a division of power aesthetically veneered in perpetual and constantly frenetic change, until it dissolves and disappears, or perhaps, is simply mimetically transformed.

\section{Bionote}

\section{Paolo Heritier}

Paolo Heritier, is Associate Professor of Philosophy of Law at Turin University. He teaches Philosophy of Law, Legal and Philosophical Anthropology, Neurosciences and the Law. He is director of collections "Humana", "Tôb" and "Anthropology of Liberty". Among his publications: Estetica Giuridica (Torino: Giappichelli, 2012), La dignità disabile, (Bologna: EDB, 2014).

80 Legendre, Argumenta Dogmatica, 147 [my translation]. 